\title{
Wildfire in Australia during 2019-2020, Its Impact on Health, Biodiversity and Environment with Some Proposals for Risk Management: A Review
}

\author{
Md. Kamrul Haque1, Md. Abul Kalam Azad1*, Md. Yeamin Hossain², Tareq Ahmed ${ }^{3}$, \\ Minhaz Uddin', Md. Mukhtar Hossain'1 \\ ${ }^{1}$ Department of Crop Science and Technology, University of Rajshahi, Rajshahi, Bangladesh \\ ${ }^{2}$ Department of Fisheries, Faculty of Agriculture, University of Rajshahi, Rajshahi, Bangladesh \\ ${ }^{3}$ Department of Plant Pathology and Seed Science, Sylhet Agricultural University, Sylhet, Bangladesh \\ ${ }^{4}$ School of Environmental Science and Engineering, Tianjin University, Tianjin, China \\ Email: ^azad.adrinwa@gmail.com
}

How to cite this paper: Haque, Md.K., Azad, Md.A.K., Hossain, Md.Y., Ahmed, T., Uddin, M. and Hossain, Md.M. (2021) Wildfire in Australia during 2019-2020, Its Impact on Health, Biodiversity and Environment with Some Proposals for Risk Management: A Review. Journal of Environmental Protection, 12, 391-414. https://doi.org/10.4236/jep.2021.126024

Received: May 25, 2021

Accepted: June 22, 2021

Published: June 25, 2021

Copyright $\odot 2021$ by author(s) and Scientific Research Publishing Inc. This work is licensed under the Creative Commons Attribution-NonCommercial International License (CC BY-NC 4.0). http://creativecommons.org/licenses/by-nc/4.0/ (c) (i) $(9)$ Open Access

\begin{abstract}
Wildfire is closely associated with human society and having its effect on earth as well as on its environment for more than 350 million years. It is a very common phenomenon from the ancient period, has hazardous effects on both environment and human life. This study mainly focuses on the review of wildfire of Australia during 2019-2020 regarding its distribution, status of fatality influences on different environmental factors, consequences and some proposals for its mitigation. In this review paper, a modified edition of the principled review methodology was followed in compiling the most reliable data to support the bushfire in Australia belonging to its causes of occurrences and impacts. The bushfire was started in mid-June in 2019, and it is still now burning in hundreds of places of different parts of Australia, and the forest of New South Wales, Northern Territory, Western Australia, Queensland and Victoria were being burnt deadly. The accumulating data exposed the year 2019 as the driest and warmest year with lowest rainfall that might be the potential causes of bushfires in Australia. Moreover, maximum forest land of Australia is covered by naturally grown Eucalyptus trees which are generally flammable and supply oil type fuel during bushfires. Bushfire deteriorates the quality of soil, water and air of the locality up to many hundreds or thousands of kilometers away in increasing the emission of toxic substances and carbon rate. Around more than 3 billion native vertebrates, 143 million mammals, 2.46 billion reptiles, 181 million birds, 51 million frogs were burnt out by bushfires of 2020 in Australia. More than US $\$ 110$ billion
\end{abstract}


financial loss has been determined due to this fire of Australia. In some cases, it is also helpful for forest land. Sometimes it helps to continue the forest ecosystem by burning unwanted plants, animals and microscopic compounds. To reduce the hazard needs proper land regulation, combination of social governance, sufficient funding, permanent vigilance of all sides are the partial solutions. However, the research helps to find out an overall idea to explore the devastating nature of bushfires, the actual causes of occurrences and recommendations for mitigation of bushfires in Australia as well as assisting researchers those willing for further scientific study. It was also mentioned some effective prologues to reduce the hazardous effects and find some ways to overcome such destructive disaster.

\section{Keywords}

Temperature, Rainfall, Human Health, Biodiversity, Environmental Effects

\section{Introduction}

Wildfires are widespread phenomenon across the world. An uncontrolled destructive fire in forest land is generally termed as wildfire. A wildfire is an unregulated fire in inflammable vegetation place happening in rural areas [1]. Changes in environmental conditions influence prevalence and severity of wildfire causing longer fire seasons and wider area covered [2] [3] [4] [5]. Due to the lightning strike or carelessness of human, it started from a small place and destroys large areas of forest land, locality and harmfully effects on the environment, ecology and properties. Sometimes it causes human death also. Wildfire breaks down the abiotic and biotic components of forest ecosystem. It may be ablaze vegetation remaining both under and over ground soil. Organic matters like plant roots are also flamed up due to land fire. Ground flame can smolder for a long period yet a whole season until conditions are favorable for growth as above land fire [6]. According to the vegetation type wildfire may be known as bushfire (in Australia), desert fire, forest fire, grass fire, hill fire, peat fire, vegetation fire, or veld fire. Fire which involves low growing as like as scrub termed as brush fire. Wild fire of south northern part of Australia is known as bushfire. Desert fire occurs in desert areas where vegetation is very low. Wildfire or prescribed fire which fire up forested areas, grass, or alpine/tundra vegetation termed as forest fires.

Wildfire is not common at large scale in Bangladesh. The area of forest land in Bangladesh is very inadequate and the vegetation of the forest is not suitable for forest fire. But in some cases, it was occurred due to the human activities. In Sundarbans which is the largest mangrove forest in the world, forest fire was occurred almost every year on a very small scale due to the activities of illegal infiltrators. Indian forest land is very risky for the wildfire. A long dry season with less rainfall increases the temperature of the forest which creates the favorable condition for fires. 


\section{Causes of Wildfires}

The main natural reasons of wildfire breakout are dry climate, lightning, volcanic eruption [7] [8]. When water loss from the soil through evapotranspiration is higher than precipitation, soil becomes dry. At these circumstances, if those dry matters come in contact with fire which is created by natural occurrences like lightning, volcanic eruption or human carelessness cause wildfire and spread destructively with the help of wind. Such conditions accelerate the inception of accidental ignition or arson giving rise to a fast moving and devastating bushfire that becomes difficult to control. The speed of fire spread in forest and grassland are $10.8 \mathrm{Km} / \mathrm{h}$ and $22 \mathrm{Km} / \mathrm{h}$ respectively [9]. Campfires, Smoking, Burning of debris, Accidents or equipment failure, Fireworks, Arson etc. are the causes of starting wild fire.

The cause of wildfires differs from place to place all over the world. Lightning is the main reason of ignition in Canada and northwest China. In Africa, Central America, Fiji, Mexico, New Zealand, South America, and Southeast Asia human activities like agricultural operation, dairy and land-conversion burning are the reasons of wildfires. In Mediterranean Basin of china human negligence is key cause of wildfires [10] [11]. Lightning strikes and human activities are jointly the main reasons of wild fire of USA and Australia [12] [13]. Coal seam fires burn in New South Wales, Centralia, Pennsylvania and different coal-sustained fires of China can also spread contiguous combustible elements [14]. Heat waves, droughts, climate convertibility for example El Nino and local weather structure such as high-pressure ridges may raise the chance and interchange the attitude of fires suddenly [15].

Dry season of Australia becomes warmer day by day, temperature increases at the rate of one degree every century which increase the recurrence and redundancy of heat waves and droughts. Three quarters of four present in total forest land of Australia is covered by Eucalyptus trees. More than hundred varieties of Eucalyptus are naturally grown where which are generally flammable and supply oil type fuel during bushfire. Large scale wildfires occurred in Siberia, Alaska, Canary Islands and in the Amazon rainforest in 2019 due to the reason of extremely hot and dry weather. The smoke comes from the fires spread on large territory and reducing air quality. In the Amazon, generally dry season is the main time for occurring forest fire.

\section{Previous Researches on Wildfire}

People live in the Australian urban periphery meet different problem due to enhancing wildfire danger and the declining of biodiversity occurred because of urbanization. Significant mutual understanding was built with the help of social education methods which related with proficient knowledge in scientific way to generate mass, simultaneous aspects on danger and give a guideline to make environmental policy [16]. The general public and wild land firefighters are exposed to smoke from wild land fires in United States every year. A current re- 
search has ascertained relationship between severe wild land fire smoke expound and heart or blood vessels disease. Studies on firefighter during and after service period demonstrate harmful condition on their health due to the up taking of excess smoke [17]. Warnings consist of forthcoming wildfires to counsel about the safety. Massive number of people is indifferent about the instruction given by fire authority. Some people stay up to evacuation, while others tried to save properties and rescue others. The research pointed out three keys information for bushfire warnings but few people are not interested to obey the instruction. First one, people have to depart from risky place before fire being dangerous. Second one is homes are impossible to save during deadly period and last one is people should go as soon as possible [18].

Different studies noticed that smoke from the wildfire hold different types of harmful elements which are responsible for respiratory problem and causes large number of mortality cases among all aged mass people [19]. A combined method form of postal survey, focus group discussions and interviews with native people was done in the Mount Lofty Ranges and Lower Eyre Peninsula of South Australia. Conclusion of the research was more than $90 \%$ of local people thought that biodiversity preservation is important to take into the account during bushfire prevention policy [20]. Australian fires characteristics demonstrated huge fluctuation on inter annual and multi-decadal time balance. The result showed that ENSO (El Niño Southern Oscillation) was the main causes for inter yearly fluctuation of fire condition stated by FFDI of Australia. Experiment also noticed that social climate change was the principle reason of the incident and excess average temperatures and potentially associated fluctuation in long term rainfall patterns [21]. To hold firm the bushfire risk, fire affected countries of all over the world are trying to suppress the fire risk. But there is very little success against the fire disaster. Fire risk become more intensifies with the changes of climate. Botswana fire which was combined reason of environmental factor, policy, land use and human activity. Research stated that fire control policy on the basis of fire exercise for land use management will be worthy for locality. Methodical fire control strategies have a secured outcome on land use and climatic necessity of fire and also support to adjust environment transformation [22].

Smoke from wildfire hold upper concentration of particulate matter (PM) than urban concentration. It causes respiratory problem of millions of people. Martine and Michael conduct a study to compare between the effects of bushfire $\mathrm{PM}_{10}$ (particles with a median aerodynamic diameter less than $10 \mathrm{~mm}$ ) and background $\mathrm{PM}_{10}$. The experiment showed that smoke of $\mathrm{PM}_{10}$ wildfire was at least as toxic as urban background of $\mathrm{PM}_{10}$ [23]. There is a significant interaction between wildfire smoke emission and particulate matter $\left(\mathrm{PM}_{2.5}\right)$ which is the reason for mortality and respiratory problem such as asthma, bronchitis, pneumonia and chronic pulmonary disease. Due to the wild land urbanization, risk from wildfire smoke increasing day by day. Fuel and smoke management have an important role for save the people from the hazard [24]. 
The studies gave preference on determine in vitro methods for the consequence of fire smoke [25]. Cristine and Nicholas conducted a study in 2010 to examine an external "gap" among wildfire hazard awareness and arrangements within different property-owners in country side affected by amenity guided in-migration in South Australia. Landowners were place to fetch their delegate to bushfire preparation in the connection into daily works, dilemmas and tradeoffs [26].

For the identification of abundance mortality and financial value of wildfire in USA over several years, Neal and his team conducted a study. Northern side of California, Oregon and Idaho in the west and Florida, Louisiana and Georgia the east were dangerously invaded by wildfire. Short term financial loss is between $\$ 11$ and $\$ 20 \mathrm{~B}$ per year with net current value of $\$ 63 \mathrm{~B}$ and long-term economic damage remains between $\$ 76$ and $\$ 130$ B every year, with net current value of $\$ 450$ B [27].

A research was conducted by Thayaparan focused in re-building program of the Victoria bushfire in 2009 indicated the role of participants like formal and informal were the social-psychological measurement for economic sustainability [28]. Fire generates pyrogenic matter like charcoal by the changing of ecosystem carbon cycling. In a eucalypt forest in eastern Australia, for the research soil carbon, charcoal and nitrogen dynamics are inquired in the peak $20 \mathrm{~cm}$ of a sandy soil. Fire removed litter but enhance the charcoal and non-charcoal SOC element together of the soils. It attributes to upper soil charcoal production and causes under-ground root mortality by incorporating soil profile. Charcoal was discriminately retained in the sandy soil that restricts the various stabilization procedures so that the inflow of dead root carbon had no effects. Charcoal incorporation and holding of the soil profile are very meaningful to carbon cycling. Charcoal increases the fire frequency of sandy soils. This effect is not only limited for upper $20 \mathrm{~cm}$ of soil [29]. Wildfire can cause water repellency and burn plant canopy, surface plants and litter can change organics into soil. Soil moisture, structure could be changed and infiltration can increase surface runoff, erosion. Sediment transport and deposition is enhanced. Organic matter mineralization, root uptake obstruction and reduced water quality by improving temperatures and nutrient concentrations. Artificial large and severe wildfire effects on water harmfully skewed [30].

\section{Wildfire around the World}

Every year, around $30-46$ million $/ \mathrm{km}^{2}$ (approx. $4 \%$ the global land surface) of the world's land surface is being burned [31] shown in Figure 1. Greece, Italy, France, Spain and Portugal are investing annually around 2500 million euro in total for fire management especially for the detection and suppression of fire [32]. In Canada, on an average US $\$ 531$ million was spent annually during the year from 2000 to 2010 for the prevention and preclusion of wildfire [33].

About 420 million years ago during Silurian period rhyniophytiod plant fossils that conserved as charcoal was the first filed wildfire. The charcoal abundance 


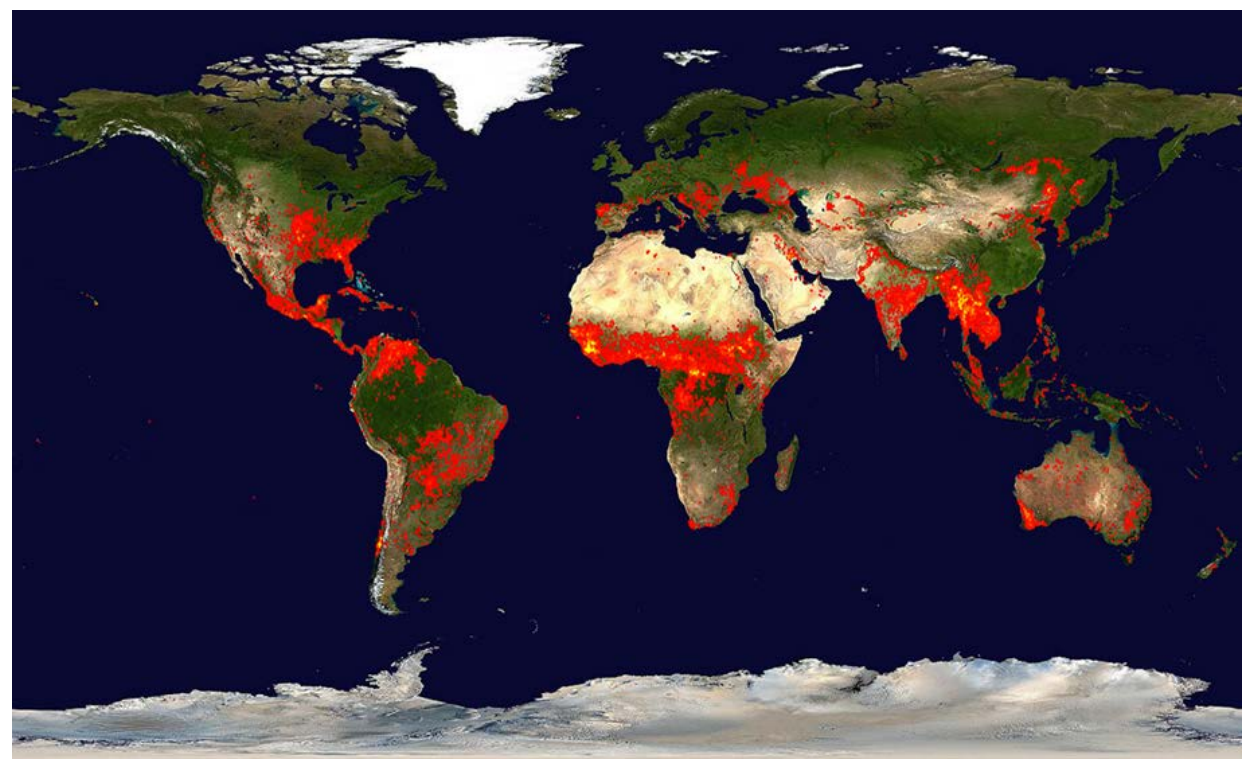

Figure 1. Global fire map by NASA [34].

during Middle and Late Devonian was related with low atmospheric oxygen [35] [36]. Because of increasing global warming rate firing and its destructive impacts increase day by day (Table 1 ).

\section{Distribution and Status of Bushfires in Australia during 2019-2020}

Australia is a wildfire amenable area. Bushfire was mainly occurred in South-eastern and South-western part of Australia during the season of summer and early autumn. The most bushfire affected area in Australia is the South-east and South-west region of the country [38] [39]. At present, annual land area burnt in Australia is around $5 \%$ which is considered to be devouring nearly $10 \%$ of the net primary productivity of the continent [40]. In North of Australia, bushfires generally happened during winter which is the dry season. In 2019-2020, a catastrophic bushfire commenced at mid-June in 2019, and it is still now burning in hundreds of places of different part of Australia especially in the South-east of the continent. In 2019, fire in New South Wales started much earlier than the previous years and since September, 2019 it covered 2.7 million hectares to be burnt. This year the affected area was three times larger than that of the Amazon (906,000 hectares) fires occurred in 2019. As the recorded data of $14^{\text {th }}$ January 2020 , fires burnt about 18.6 million hectares, destroyed over 5900 buildings and killed many people [41]. NASA calculated that 337 million tons of $\mathrm{CO}_{2}$ was emitted during this firing [42]. Forest of Eastern, North-eastern Victoria, New South Wales and the Australian Capital Territory were deadly burnt. State of emergency was declared by the authorities for these states shown in Figure 2.

About 480 million mammals, birds, and reptiles were destroyed since September by bushfire and later expanded to a billion was estimated by The University of Sydney [44]. Thousands of species of extinct plants were burnt. 


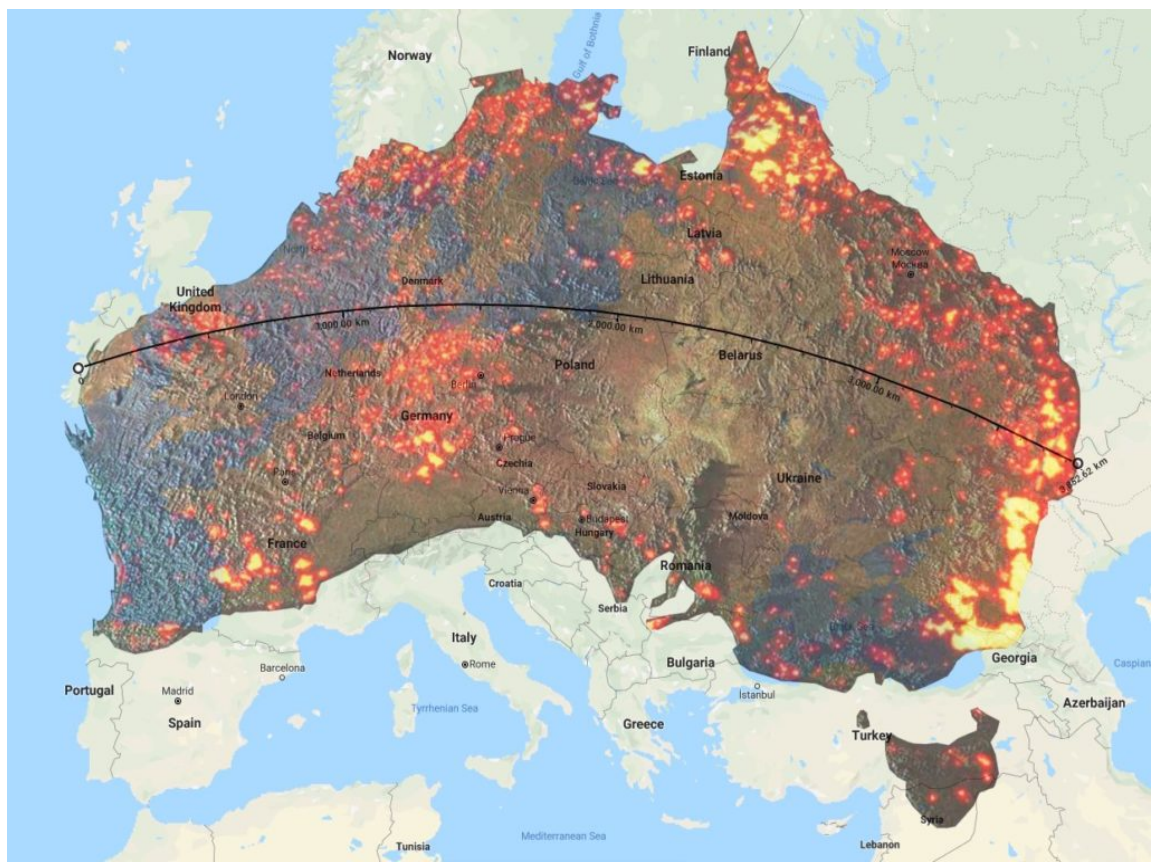

Figure 2. Fire affecting area compare with Europe during 2019-2020 seasons in Australia [43].

Table 1. Some destructive wildfire (2010-2020) around the world.

\begin{tabular}{|c|c|c|c|}
\hline Name & Region & Time & $\begin{array}{l}\text { Destroyed } \\
\text { Area (ha) }\end{array}$ \\
\hline $\begin{array}{l}\text { Australian bushfire } \\
\text { season } 2019-2020\end{array}$ & South-east Australia & September 2019-2020 & $18,636,079$ \\
\hline Siberia wildfire 2019 & Siberia & July-September 2019 & $3,000,000$ \\
\hline Alberta wild fire 2019 & $\begin{array}{l}\text { Northern \& Central } \\
\text { Alberta, Canada }\end{array}$ & March-December & 883,414 \\
\hline Amazon wildfires 2019 & $\begin{array}{l}\text { Brazil, Bolivia, } \\
\text { Paraguay, Peru }\end{array}$ & January-2020 & 906,000 \\
\hline British Columbia wildfires 2018 & British Columbia, Canada & August-September & $1,351,314$ \\
\hline Sweden wildfire 2018 & Sweden & May-August & 25,000 \\
\hline Russian wildfire 2018 & Amur Oblast, Russia & May-July & 321,255 \\
\hline California wildfires 2018 & California & February-December & 766,439 \\
\hline British Columbia wildfires 2017 & British Columbia, Canada & July-September & $1,216,053$ \\
\hline Wildfires of Russia 2015 & $\begin{array}{l}\text { Inner Mongolia, } \\
\text { China and Russia }\end{array}$ & Mid April & $1,100,000$ \\
\hline $\begin{array}{l}\text { Northwest Territories, } \\
\text { Canada } 2014\end{array}$ & $\begin{array}{c}\text { Northwest Territories, } \\
\text { Canada }\end{array}$ & Summer & $3,500,000$ \\
\hline $\begin{array}{c}\text { Richardson Backcountry } \\
\text { Fire } 2011\end{array}$ & Alberta, Canada & May-September & 705,075 \\
\hline Bolivia Forest fires 2010 & Bolivia & August & $1,500,000$ \\
\hline Russian wildfire 2010 & Russian wildfire 2018 & July-September & 30,000 \\
\hline
\end{tabular}

Source: [37]. 
(Table 2) New South Wales, Northern Territory, Western Australia, Queensland and victoria were being terribly damaged. Though the fire stopped in some places after the rain of January but in many places, fires are still alive like New South Wales. Even Canberra the capital is still at risk of burning. Australia spends around $\$ 375$ million every year in the management of bushfire with a rise in costs of $2.2 \%$ per year [45]. Around \$8.2 million was spent for Sydney health services due to bushfire in the year of 2011, and it is estimated to increase its demands on health resources in the near future [39] [46].

\section{Causes of Fire Abnormality during 2019-2020}

According to annual climate statement 2019, it was the warmest year in Australian History (Table 3). During 2019, the average increasing temperature of Australia was $1.52^{\circ} \mathrm{C}$ and the previous record was $+1.33^{\circ} \mathrm{C}$ in the year of 2013. The maximum and minimum mean increasing temperatures were recorded $2.09^{\circ} \mathrm{C}$ and $0.95^{\circ} \mathrm{C}$ respectively.

Table 2. Damaged area in Australia during the bushfire of 2019-2020.

\begin{tabular}{ccccc}
\hline State/Territory & Area in hectors & Number of fires & House lost & Live lost \\
\hline Australian Capital Territory & 60,000 & - & - & - \\
New South Wales & $5,595,739$ & 10,520 & 2475 & 25 \\
Northern Territory & $6,800,000$ & - & 5 & 0 \\
Queensland & $2,500,000$ & - & 48 & 0 \\
South Australia & $2,86,845$ & 1324 & 186 & 3 \\
Tasmania & 36,000 & - & 2 & 0 \\
Victoria & $1,505,004$ & 3500 & 396 & 5 \\
Western Australia & $2,200,000$ & - & 1 & 0 \\
Total & $18,983,588$ & 15,344 & 3113 & 33 \\
\hline
\end{tabular}

Source: [37].

Table 3. Average increasing temperature of Australia along with its different area in 2019.

\begin{tabular}{cccc}
\hline Temperature & $\begin{array}{c}\text { Maximum } \\
\text { Temperature }\left({ }^{\circ} \mathrm{C}\right)\end{array}$ & $\begin{array}{c}\text { Minimum } \\
\text { Temperature }\left({ }^{\circ} \mathrm{C}\right)\end{array}$ & $\begin{array}{c}\text { Mean Temperature } \\
\left({ }^{\circ} \mathrm{C}\right)\end{array}$ \\
\hline Australia & $2.09^{* *}$ & 0.95 & $1.52^{* *}$ \\
Queensland & 1.46 & 1.09 & 1.27 \\
New South Wales & $2.44^{* *}$ & 1.45 & $1.95^{\star *}$ \\
Victoria & 1.37 & 0.72 & 0.41 \\
Tasmania & 0.64 & 0.17 & $1.45^{\star}$ \\
South Australia & $2.30^{* *}$ & 0.59 & $1.67^{\star *}$ \\
Western Australia & $2.50^{* *}$ & 0.83 & $1.49^{\star}$ \\
Northern Territory & $1.97^{* *}$ & 1.02 & \\
\hline
\end{tabular}

${ }^{*}$ Highest record; ${ }^{\star S}$ econd Highest record. 
Figure 3 demonstrated the rainfall data of Australia from the year of 1970 to 2019. Data of rainfall has been represented every 2 year interval. At the very beginning of the time span, rainfall was nearly $400 \mathrm{~cm}$ with its rising trends. It reached its peak in the year of 1974 i.e. about $750 \mathrm{~cm}$. The rainfall pattern demonstrated a sharp decrement up to 1977 and a fluctuating trend remained till 1994 made it as the driest year. Again, there was a rising trend of rainfall reaching $700 \mathrm{~cm}$ in 2000 and 2010 [47].

The lowest rainfall was observed in the year of 2019 and it was remarkably low as reached about $280 \mathrm{~cm}$ rainfall annually. Such a dry season with minimum rainfall may be a potential cause of bushfire in Australia (Figure 3).

The temperature of Australia exposed a wide range of variation from the year of 1970 to 2019 (Figure 4). All over this time span, average temperature was fluctuating frequently ranging from $-0.75^{\circ} \mathrm{C}$ to $+1.5^{\circ} \mathrm{C}$. The lowest average temperature was recorded in the year of 1976 falling to $-0.75^{\circ} \mathrm{C}$ and the highest was reported in 2019 reaching to $+1.5^{\circ} \mathrm{C}$. It was always below $+1^{\circ} \mathrm{C}$ before the year of 2005. However, in 2005 it crossed $+1^{\circ} \mathrm{C}$ for the first time and in 2019 it reached the highest temperature at the rate of $+1.5^{\circ} \mathrm{C}$ (Figure 4), and such a high increasing temperature could have a positive impact in occurring bushfire in Australia.

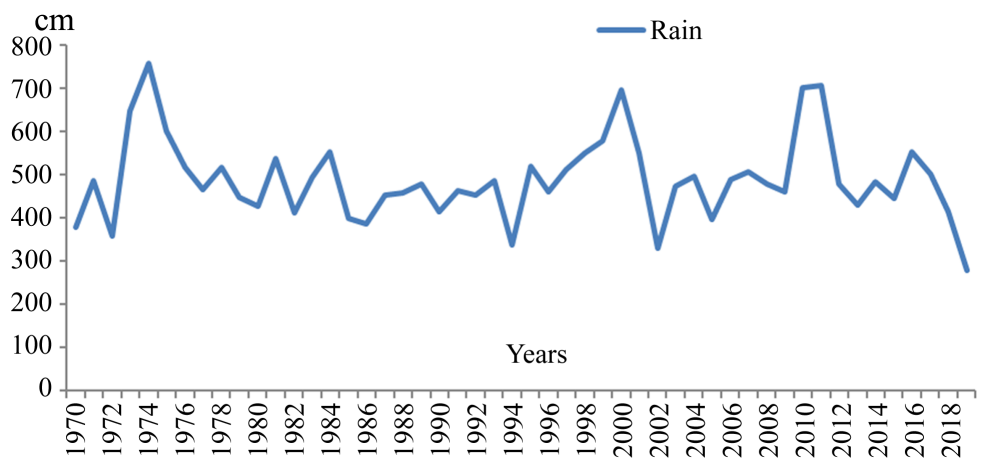

Figure 3. Average rainfall of last fifty years.

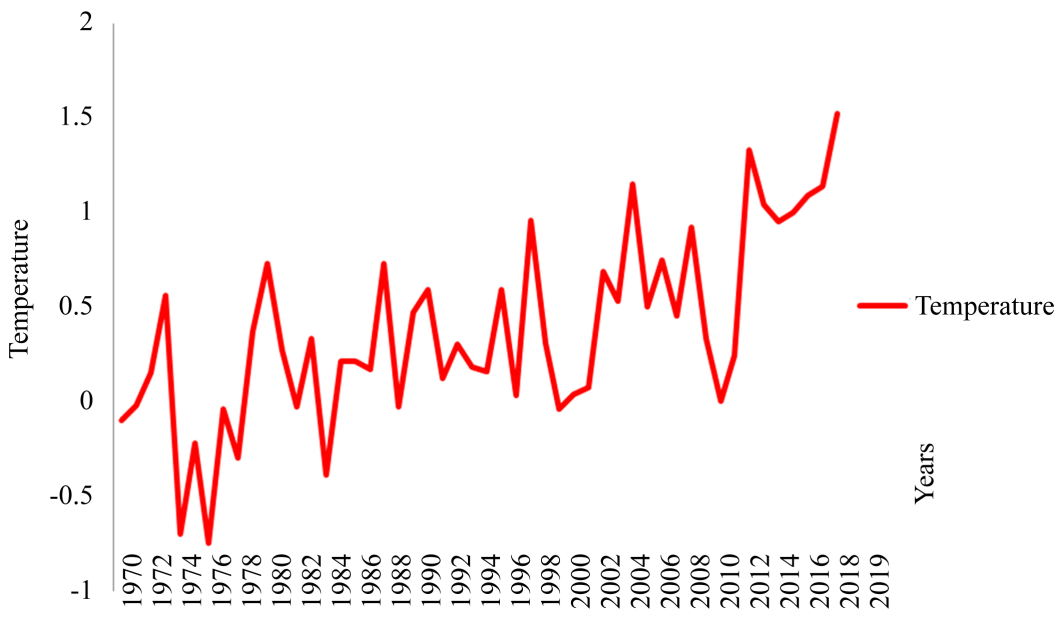

Figure 4. Inconsistency of average temperature of Australia. 
The year started with rainfall scarcity across massive areas of eastern Australia. The unexpected less precipitation throughout 2019 caused severe moisture deficiencies. The Murray-Darling Basin was the main sufferer as an area of the low moisture content. The average annual soil moisture recorded in five of the 26 river catchments of the Basin was the lowest during the year 2019.

Scarcity of moisture in soil restricted the surface runoff. Winter to spring is mainly the repletion time for water storages for Southern and Southeastern Australia. Limited river flow since last three years and less runoff caused marginal fill-up to storages across the Southern Basin by the year and no significant undercurrent in the Northern Basin where storages was close to zero.

At the end of 2019, moisture storage had declined to less than $7 \%$ in the Northern Murray-Darling Basin. In the Northern Basin water storage condition was lower than any time during the Millennium Drought (2001-2009). In the Southern Basin 53\% volume of moisture storage in January down to $39 \%$ at the end of April 2019 which was the irrigation season.

The storages had prolonged $47 \%$ by the end of the recovery time and diminished once again from spring to summer. Effect of the below average rainfall during reserving period also affected coastal New South Wales, Eastern South Australia, Eastern Victoria, Northwestern Victoria, East coast and North coast Tasmania and the South West part of Western Australia (Table 4).

The highest daily record of FFDI values for spring was experienced in areas of all States and Territories of Australia (Figure 5). Across northern Australia, the Grassland Fire Danger Index (GFDI) is more routinely used to assess fire weather conditions. Nevertheless, several fires started across northern Australia with FFDI values the highest was record for spring across the large areas.

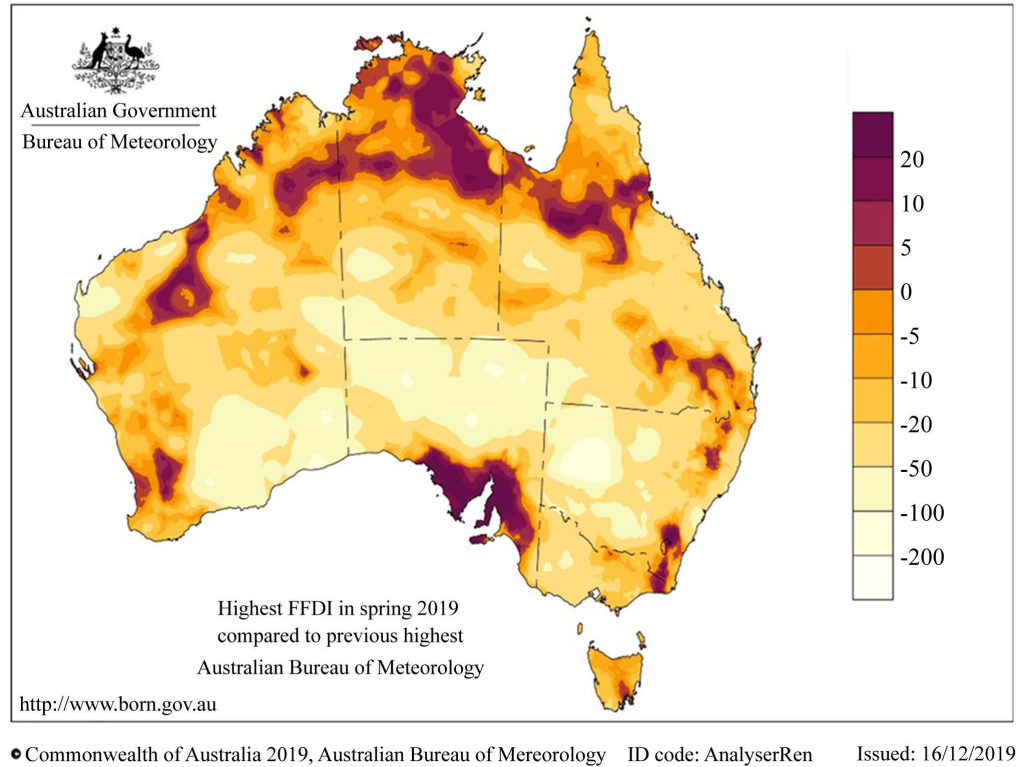

Figure 5. Comparison of the highest daily FFDI in spring of 2019 and the previous maximum data for spring during 1950-2018. Dark colors show the top FFDI for spring [47]. 
Table 4. Average rainfalls in different regions of Australia during 2019-2020.

\begin{tabular}{|c|c|c|c|}
\hline & Average rainfall $(\mathrm{mm})$ & Deviation from mean (\%) & Remark \\
\hline Australia & 277.6 & -40 & lowest \\
\hline Queensland & 497.3 & -20 & \\
\hline New South Wales & 250.2 & -55 & lowest \\
\hline Victoria & 473.1 & -28 & $\begin{array}{c}\text { Lowest } \\
\text { (since 2006) }\end{array}$ \\
\hline Tasmania & 1298.3 & -7 & \\
\hline South Australia & 80.0 & -65 & lowest \\
\hline Western Australia & 173.7 & -49 & $2^{\text {nd }}$ lowest \\
\hline Northern Territory & 268.1 & -50 & $2^{\text {nd }}$ lowest \\
\hline Murray-Darling Basine & 228.3 & -53 & lowest \\
\hline
\end{tabular}

Source: [47].

\section{Overall Effects of Australian Mega-Wildfires, 2019-2020}

\subsection{Effects on Human Health}

Bushfire produces various toxic substances and the smoke has harmful outcome on human inhalation organ. In 2009, 173 deaths were reported for the Victorian Black Saturday bushfires in which 77 were children, senior citizens or people with respiratory disability [48]. Mental health problems were observed among the residents and fire fighters four years after the event [49]. Fire fighters or people near the fire are remained at highly danger of carbon monoxide (CO) take in as well as other detrimental components which in turn lead to unconsciousness and even death [50]. Around 5\% increase in non-accidental deaths were reported by different Australian studies on days of high air pollution from bushfire smoke [51]. Smoke from wild fire consists of numerous hazardous air pollutants including carbon monoxide (CO), nitrogen dioxide, ozone, particulate matter (PM), polycyclic aromatic hydrocarbons (PAHs), and volatile organic compounds [52]. Besides, bushfires have the respiratory problems, adverse cardiovascular effects as the smaller particles $\mathrm{PM}_{2.5}$ can enter into the bloodstream causing blocking of blood circulation and even death [53].

A study over smoke from bushfire in Sydney, Australia, showed a positively rise in mortality [54]. Every year 339,000 ill-timed fatality caused due to wildfire all over the world [51]. In Newcastle, Australia, a study showed that risk of pneumonia and acute bronchitis increases with the high-level smoke up take during fire [55]. There is a significant relation among wildfire smoke exposures and a failure of lung function into asthmatic problem free children [56]. In a panel study in Australia of full-aged and kiddies, smoke from forest fire was found in influencing the use of reliever cure and start oral steroid. People with 65 years old or higher are more likely to be respiratory hospitalized than the younger exposing to the destruction of all living organisms in the Brazilian Amazon and wildfire smoke in Australia [54] [57]. Number of heart disease at- 
tacked patients out-of-hospital were connected with bushfire-involved $\mathrm{PM}_{2.5}$ in Australia [58]. Hazardous smoke from wildfire may cause fine particle air pollution creates various types of severe problem for human health. Hazardous gaseous mixtures are also harmful for visional organ and respiratory system and causes lung difficulties, bronchitis, asthma and premature death. Fire causes mental stress that faces emergency condition and lost their properties.

\subsection{Effects on Biodiversity}

Bushfire is a common phenomenon in Australia. Around more than 3 billion native vertebrates excluding invertebrates comprise about 143 million mammals, 2.46 billion reptiles, 181 million birds, 51 million frogs were burnt out by bushfires of 2020 in Australia stated by the World wildlife Found Australia [59]. Various types of extinct varieties plants are found in the forest of Australia. Scientist feared that some of them would fully destroy from their natural habited. It occurs at a small area, but in other place the endangered animal remains safe but in the present fires spread through the all part of their habited which create the possibility of die out of some endangered species. Kangaroo Island was the living place of sea lions, penguins, kangaroos, koalas, pygmy possums, southern brown bandicoots, ligurian bees, Kangaroo Island dunnarts and glossy black cockatoos. In the rainforest, fire threatens the collection of species diversity and emitted large volume of $\mathrm{CO}_{2}$. About $33 \%$ forest land was destroyed by the land fire of 2019-2020 (Figure 6). Less than 500 Kangaroo Island dunnarts and about 380 Kangaroo Island glossy black cockatoos remain in nature only in the
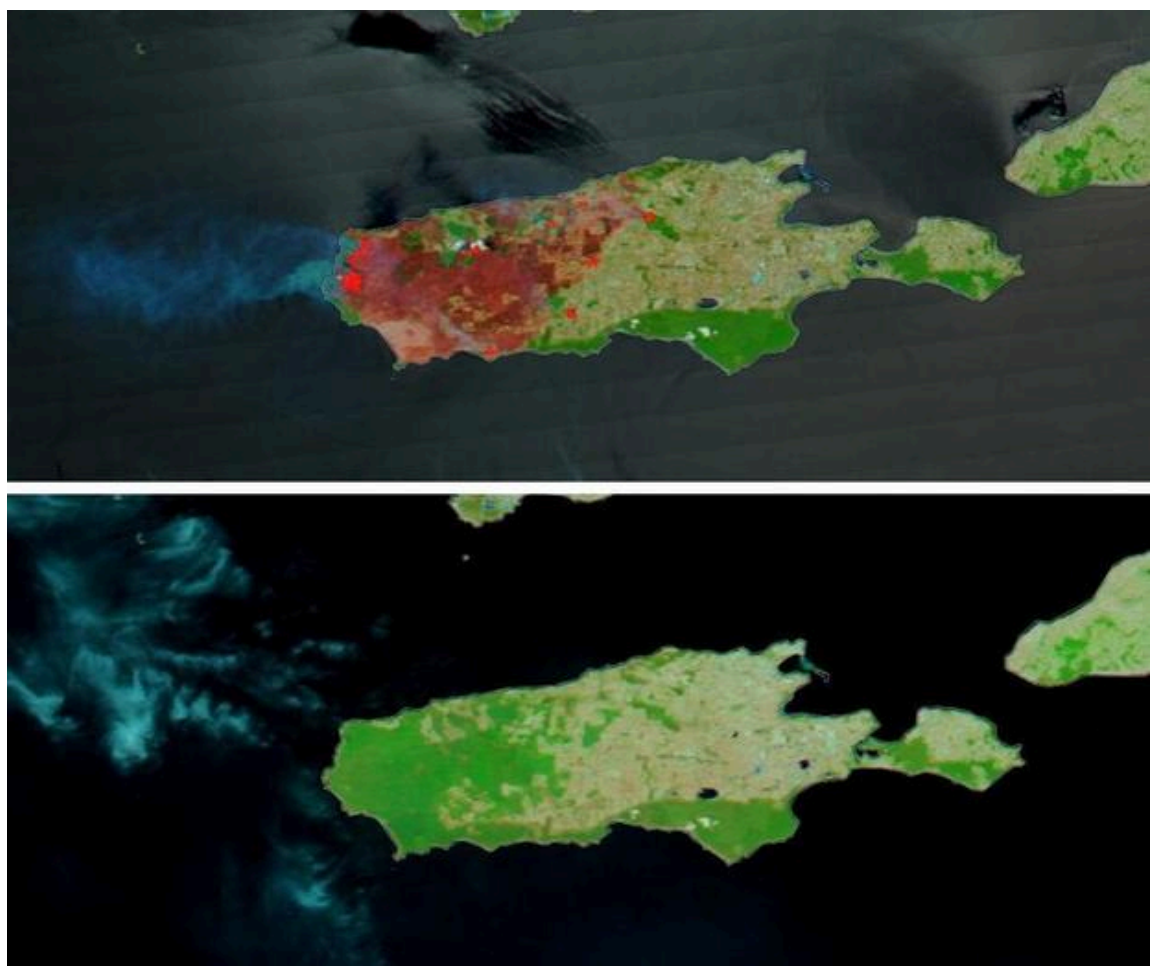

Figure 6. Satellite image of Kangaroo Island after and before burn by NASA [71]. 
island [60]. Ecologists feared about the species would lose from the nature. Onthophagus weringerong, Thyregis kershawi species of beetles; Euastacus bidawalus, E. guwinus, E. spinifer, E. vesper species of Crayfishes; Acletoxenus formosus, Leucophenga subpollinosa, Scaptodrosophila eluta, S. jackeyi species of Flies; Austrochloritis kippara, Coricudgia wollemiana, Egilodonta bendethera, Egilomen sebastopol, Gyrocochlea janetwaterhouseae, Hedleyropa yarrangobillyensis, Letomola lanalittleae, Macrophallikoropa stenoumbilicata, some species of snails; Aname caeruleomontana, A. helensmithae, A. horsemanae, A. macei, Austrarchaea mcguiganae, Austrarchaea monteithi, Austrarchaea smithae are some species of spider were totally burnt in the fire of New South Wales [61].

\subsection{Effects on Environment}

Bushfire increases threat to environmental pollution and impacts. Environmental components are highly vulnerable to bushfire.

\subsubsection{Effects on Air}

Most notably, bushfire deteriorates the air quality of the locality up to many hundreds or thousands of kilometers away [62]. Bushfire highly increases the carbon emission rate, the air quality index (AQI) of west environs of Sydney known as Rozella was 2552 which is 12 times more than risky level of 200 [63]. According to the survey of January 2020, the world's worst air quality of any important town was Canberra. On 1 January 2020, AQI was calculated as 4650 around Monash of Canberra, which is more than 23 times dangerous level [64]. On the first Day of 2020, smoke created from the bushfire of Australia covered the sky of South Island of New Zealand and turned into orange-yellow gloom. The smoke affected glaciers of the New Zealand and created a brown tint to the snow. On 5 January 2020, the sky in Auckland also turned into orange due to the smoke [65]. By 7 January 2020, the smoke was flown about 11,000 kilometers over the South Pacific Ocean and spread to Chile, Argentina, Brazil, and Uruguay [66].

\subsubsection{Effects on Soil}

Wildfire hazardously effects on soil quality and soil structure. It may change the soil structure, reduces availability of some important nutrient like N, P \& S. Potassium, calcium, and magnesium ions concentration should be increased because of bushfire in the soil. Fire reduces the water holding capacity. Cation exchange capacity, organic chelation, aggregate stability, macro pore space, infiltration, and soil microorganisms are highly affected because of excess temperature during burning of soil in land fire. High intensity of fire reduces the productivity of soil due to the reducing availability of nitrogen in soil but in the case of productivity low intensity of fire shows the opposite result. Soil structures are affected by fire. The organic compound may be crack up at less temperature. The bulk density of the damage soil is increased which causes reduction of its porosity. Low porosity of soil reduces the fertility and turned the soil into more 
permeable to post fire runoff and soil erosion [67]. During wildfire, temperature of surface soil can be reached up to $900^{\circ} \mathrm{C}$. High-temperature totally burns the surface organic layers causes the organic material mineralized or volatilized during oxidation. It enhances the excessive soil erosion from the upper layer of the forest land. Mulching with natural cover or a litter and other organic material of surface of the soil prevent the excessive soil erosion rates. Fires burn the cover of the surface soil and enhance soil erosion [68]. Acidity of non-calcareous soil at post-fire condition should be increased, because of the addition of alkaline cations like $\mathrm{Ca}, \mathrm{Mg}, \mathrm{K}, \mathrm{Na}$ etc. to the soil organic component. For the development of iron oxides soil turned into dark color [69].

\subsubsection{Effects on Water}

Wildfires have hazardous effects on rivers, lakes, and streams. After wildfire when the first rain drops, burnt soil became hydrophobic causes of storm water runoff. The water moves through the surface of the ground. This water carries harmful chemicals, various pollutants and other hazardous chemical into streams, rivers, and large bodies of water and they destroy the balance of water ecosystems. Post-fire flash flood is great impendence for water bodies. These floods contain heavy metal from ash and killed under water vegetation, living organisms. Wildfire reduces the drinkable water sources. Fire changes the hydrologic cycle that causes soil erosion, sedimentation and water quality. When fire occurs on wetland the principal changes are addition of sediment, increase nitrates where the foliage are being burnt in the area of chronic atmospheric deposition, possibility of heavy metals contamination from soils and geological sources to water bodies in the burnt area and the fire retardant chemicals can wash into water sources which increase toxicity levels to water-born components

[67]. Bushfire ash contains nitrogen and phosphorous. Excess concentration of these nutrients causes the growth of cyanobacteria which reduces quality of water, along with bad taste, odder and harmful chemicals also. The ash also blows through the ocean and create the same problem. Algae take oxygen in the water for growing itself and assuage dissolved oxygen after their death and during decomposition. It may throttle aquatic animal and other marine life and hampers to biodiversity. After a burn, stream flow can transport solid and dissolved materials that degrade water quality [70].

\subsection{Effects on Agriculture}

The bushfires have scorched pastures, killed cattle, and burnt vineyards, with regrowth and regeneration likely to strain already depleted water supplies. According to reports, the country's dairy supply will be hit the hardest, with Victoria and New South Wales-two of Australia's most important milk-producing states-suffering the most farmland and infrastructure disruption. Meat, wool, and honey production may all be affected. According to Meat \& Livestock Australia, about $13 \%$ of the national sheep flock is in areas that have been substantially impacted, with another $17 \%$ in areas that have been partially impacted 


\section{[72].}

\subsection{Effects on Economy}

Fire has its both direct and indirect effects. It causes huge economic losses of the people directly as well as other factual effects on community by diagonal impacts among which flooding, soil erosion, mass movement and pollution of water are considered to be the most important post-fire effects with the highest consequences on society [73] [74] [75]. Due to the fire of Australia in 2019-2020, more than 110 billion USD financial loss have been determined which largely exceeding the previous Black Saturday fires occurred in 2009 was 4.4 billion USD [76]. AM Best credit rating agency stated that bushfires cause 1.7 billion Australian Dollar insurance losses and it might be increased they thought [77].

\subsection{Beneficial Effects}

Though bushfire is very destructive and harmful for environment and human being, but in some cases it has beneficial impacts also. It helps to survive some plants like manzanita, chamise (Adenostoma fasciculatum) and scrub oak (Quercus berberidifolia) which need heat before germination. Wildfires may destroy pest and infectious agents those affect plants and animals. At a low intensity fire removes the unwanted stem and leaves and cleans the bush of grass from the surface of the forest land which enriches the soil with nutrients and creates place for sunlight and air flow in to the ground. The sunlight rears lesser living organism and creates big trees space for arising and prolonging. Fire also helps to burn germ of pestilence disease [78] (Table 5).

\section{Proposals for Fire Risk Management}

The bushfire or forest-fire is known as the decimation of nature by landscape fires raging out of control. The bushfire problem has no specific solution. Combination of social governance, public and personal land management, suppression efficiency and personal arrangement are one of the partial solutions. To reduce the hazard needs proper land regulation, sufficient funding and the permanent vigilance of all sides.

\subsection{Restriction of Entrance into Forest Land}

Forests have the own ability to re-birth after disaster. To regenerate itself undisturbed condition should be maintained. Sundarbans is the world's largest mangrove forest in Bangladesh. After the destruction of cyclone "Sidar" in Bangladesh during 2007, largest area of this forest became disorganized. Thousands of plants, animals and plant were died. Food chain of the ecosystem fallen in great threat. To revive the situation, at first the Government of Bangladesh restricted the entrance of tourists, fisherman and forest dependable people into forest. The ecologist thought that the forest took lots of year to recover itself. Nature disproves them and became self-reliant. However, restriction should be employed 
Table 5. Overall impacts at a glance of Australian mega bushfires of 2019/2020.

\begin{tabular}{|c|c|}
\hline Component & Impacts \\
\hline Air & $\begin{array}{l}\text { - In fire-affected states, air quality has been destroyed [62], and the Air Quality Index (AQI) has been raised [63]. } \\
\text { - According to a NASA survey conducted in mid-December 2019, the wildfires in New South Wales and } \\
\text { Queensland have produced } 250 \text { million tonnes of } \mathrm{CO}_{2} \text { since } 1 \text { August. NASA later reported that as of } \\
\text { January 2, 2020, } 306 \text { million tonnes of } \mathrm{CO}_{2} \text { had been released [64]. } \\
\text { - Fine particles known as } \mathrm{PM}_{2.5} \text { were detected at } 734 \mathrm{~g}(0.01133 \mathrm{gm}) \text { in Sydney, which is the equivalent of } 37 \\
\text { cigarettes and Smoke gave the snow a brown tint, and the sky in Auckland turned orange [65]. }\end{array}$ \\
\hline Soil & $\begin{array}{l}\text { - Australia's bushfires in } 2019 / 2010 \text { devastated millions of hectares of land, destroying both above-ground plant } \\
\text { and under-ground root systems and soil. } \\
\text { - The fire in the year 2019-20 was strong enough to radiate heat into the underlying soil layers that lost the soil's } \\
\text { aggregate, soil organic matter and essential nutrients. }\end{array}$ \\
\hline Water & $\begin{array}{l}\text { - In Australia, cyanobacterial blooms and an imbalanced aquatic ecology have been recorded. Organic matter, } \\
\text { salts and metal trace from ash burned vegetation into the water source have been observes regarding the } \\
\text { 2019/20 season which reduced dissolved oxygen triggering fish deaths in Australia. } \\
\text { Following the } 2019 \text { bushfires, rainstorm transported a considerable amount of ash into groundwater in NSW } \\
\text { and other impacted states, resulting in higher chlorine levels, turbidity and an unpleasant smell [79]. }\end{array}$ \\
\hline Biodiversity & $\begin{array}{l}\text { - About } 143 \text { million animals, } 2.46 \text { billion reptiles, } 181 \text { million birds, and } 51 \text { million frogs were affected [59]. } \\
\text { According to a report of Aljazeera.com, at least } 3 \text { billion terrestrial vertebrates were moved or killed by the } \\
2019 / 20 \text { bushfires [80]. } \\
\text { - The Kate's leaf-tailed gecko's habitat was completely destroyed by the fires, while the long-footed potoroo's } \\
\text { habitat was reduced by more than } 80 \% \text { [81]. } \\
\text { - Kangaroo Island forest land, which is the last habitat of Kangaroo Island dunnarts and Kangaroo Island glossy } \\
\text { black cockatoos, was devastated to the tune of } 33 \% \text { [82]. } \\
\text { - According to NASA, the number of deceased koalas on Kangaroo Island could be as high as } 25,000 \text {, or roughly } \\
\text { - half of the species' overall population [83]. } \\
\text { - Ane-quarter of Kangaroo Island's Ligurian honey bee hives were destroyed [84]. } \\
\text { the results of the study were discovered and it was thought that they were completely destroyed or displaced [85]. }\end{array}$ \\
\hline Food safety & $\begin{array}{l}\text { - Agricultural production, as well as average farm income, has fallen by } 8 \% \text { in } 2019 / 20 \text {, some } 4 \% \text { below the } \\
\text { Australian } 10 \text { year average [ } 86 \text { ]. } \\
\text { - The farm income in the NSW following } 2019 / 20 \text { bushfires was almost zero, according to ABARES. As poor as the } \\
\text { last } 20 \text { years and significantly lower than the average in certain territories [ } 86 \text { ]. } \\
\text { - Total agricultural exports from Australia are expected to decrease in } 2019-20 \text { by } 11 \% \text { to USD } 43 \text { billion [ } 86 \text { ]. }\end{array}$ \\
\hline Human health & $\begin{array}{l}\text { - } 417 \text { people died of heavy smoke following the } 2019 \text { season of bush fires [87]. } \\
\text { - After the black summer bush fire, the most frequent complaints were eye and throat pain, cough and headaches [88]. } \\
\text { - Bushfire smoke caused } 2027 \text { people in respiratory problems and } 1305 \text { persons with asthma-related } \\
\text { conditions in hospitals according to a recent study [88]. } \\
\text { - Around } 1100 \text { people were hospitalized caused by cardiovascular complications due to fires } \\
\text { - Activities at Canberra Hospital were delayed by bushfire smoke contaminating the interior air, which impacted } \\
\text { MRI machines, and numerous surgeries were postponed during the 2019-20 bushfires [89]. } \\
\text { - In "highly impacted" communities where people died or property was damaged, people suffered more than } \\
\text { twice as much from post-traumatic stress disorder (PTSD), depression and mental anxiety. }\end{array}$ \\
\hline
\end{tabular}

in entrancing into the forest land including Australian forest which might be reduced the probability of firing of forests.

\subsection{Supplying Food and Create Water Bodies for Wild Animal}

Fire burnt the sources of food and destroyed food chain of a forest. To reconstruct the ecosystem, it is essential to supply food when fire occurred in large scale. Bushfire also degrades the water quality of the entire water sources of the 
forest which are the source of drinking water of the wild animal. In post-fire period scarcity of drinkable water is very common matter. Burnt organic compound of the soil washed away to the water bodies and pollute them. Supply of pure water should be ensured and needed to purify those sources of water which are being contaminated during fire.

\subsection{Increasing Soil Microbial Activities to Reduce Soil Erosion}

Fire burns the upper surface of the soil. Burnt soil reduces its water holding capacity. Fire also destroys below ground root systems which loosen the soil and causes the soil erosion. After heavy precipitation the rate of soil erosion becomes extremely high. To maintain the soil microbial activities, it is necessary to take proper step for increasing soil organic matter to protect the soil erosion.

\subsection{Reducing the Number of Eucalyptus Plant from Human Locality}

Eucalyptus species are the native plant of the Australian forest. Hundreds of varieties are grown naturally in this area. Eucalyptus plant produces oil like flammable substances and increase the fire spread rate during wildfire. To control the fire occurrence, it is important to reduce the number of Eucalyptus plants from human habitat area but it is very hard and tuff task.

\subsection{Using Eco-Friendly Fuel to Reduces the Temperature}

Average temperature of Australia is increasing year after year. Australia is dependent on fossil fuel for maximum energy production. Fossil fuel emitted carbon dioxide which is responsible for green house effects. However, to decrease the temperature, dependence on fossil fuel should be reduced. Eco-friendly fuel should be introduced.

\subsection{Creating Wild Life Sanctuary to Protect Endangered Species}

Wild life Sanctuary is a place where hunting of wild animal is strictly prohibited. Endangered wild animals are able to increase their number in their own habitat without any obstacle. Sundarbans is the last natural habitat of Royal Bengal tiger of Bangladesh. The forestry department announces three wildlife Sanctuaries in different parts of the forest which helps in increasing the number of tiger day by day.

\subsection{Creating Awareness among the Mass People}

Maximum time wildfire is occurred due to carelessness of human being. People enter into the forest for different purposes like agricultural activities, hunting, campfire etc. They firing in a small scale but forgot to put off the fire. This spreads with the help of wind and caused wildfire. In some cases during forest fire some people remain in their own habitat to save properties which causes life damage. To avoid these types of situation public awareness is highly important. 


\subsection{Planning for Environmentally Sound Development Project}

Development and environment are closely related with each other. Development program without concerning environment is harmful for society. $\mathrm{CO}_{2}$ emission rate, greenhouse effects, global worming etc. are most mooted issue of the current world. To make a safe world for future we have to be concern about our environment. Our movement has to be environmentally friendly.

\subsection{Increasing Forest Density}

By protecting present forest area and revegetating new trees surrounding forest land to ensure access to fire refuges for mobile species during fire. Unburn habitat would be found out for threatened animals and plants to save them. Fire rescue action for endangered animal and plant protection should be created. Quick response teams would be set up to evaluate and minimize impacts on endangered species.

\section{Conclusion}

Wildfire is a common phenomenon from historical period, with the change of climate and environment increase the rate of damage from natural disaster. It supplies more $\mathrm{CO}_{2}$ to the earth which is the main factor for greenhouse effect. Wildfire is not fully curable but worry about the disasters helps us to reduce the adverse effect. The average temperature of the world is increasing every year. Glaciers are melting which raises the sea level. Every year a lot of lands go under the water that increases the salinity of the soil. Salinity reduces the soil fertility and production of food, queered the food safety. To minimize the causality of the disaster we should have to be wake up together. Long term plan should be formulated. We have to change our mentality to save the world. If the change not started from our own door, it is impossible to change the world.

\section{Conflicts of Interest}

The authors declare no conflicts of interest regarding the publication of this paper.

\section{References}

[1] Davies, A., Brown, A., Elder, C., Hill, K., Lumley, T. and McNamara, T. (2008) Cambridge Advanced Learner's Dictionary. 3rd Edition, Cambridge University Press, Cambridge.

[2] Westerling, A.L., Hidalgo, H.G., Cayan, D.R. and Swetnam, T.W. (2006) Warming and Earlier Spring Increase Western US Forest Wildfire Activity. Science, 313, 940-943. https://doi.org/10.1126/science.1128834

[3] Settele, J., Scholes, R., Betts, R., Bunn, S., Leadley, P. and Nepstad, D. (2014) Terrestrial and Inland Water Systems. In: Field, C.B., Barros, V.R., Dokken, D.J., Mach, K.J., Mastrandrea, M.D. and Bilir, T.E., et al., Eds., Climate Change 2014: Impacts, Adaptation, and Vulnerability, Part A: Global and Sectoral Aspects. Contribution of Working Group II to the Fifth Assessment Report of the Intergovernmental Panel 
on Climate Change, Cambridge University Press, New York, 271-359.

[4] Flannigan, M., Cantin, A.S., de Groot, W.J., Wotton, M., Newbery, A. and Gowman, L.M. (2013) Global Wildland Fire Season Severity in the 21st century. Forest Ecology and Management, 294, 54-61. https://doi.org/10.1016/j.foreco.2012.10.022

[5] Gillett, N.P., Weaver, A.J., Zwiers, F.W. and Flannigan, M.D. (2004) Detecting the Effect of Climate Change on Canadian Forest Fires. Geophysical Research Letters, 31, Article ID: L18211. https://doi.org/10.1029/2004GL020876

[6] National Geographic (2021) Wildfires. National Geographic, Washington DC. https://www.nationalgeographic.org/encyclopedia/wildfires

[7] National Wildfire Coordinating Group (2008) Wildfire Prevention Strategies. National Wildfire Coordinating Group, 17.

[8] Scott, A. (2000) The Pre-Quaternary History of Fire. Palaeogeography, Palaeoclimatology, Palaeoecology, 164, 281-329.

https://doi.org/10.1016/S0031-0182(00)00192-9

[9] Nhmu.utah.edu. (2007) All About Wildfires: The Science behind Wildfire. https://nhmu.utah.edu/sites/default/files/attachments/All\%20About\%20Wildfires.p df

[10] Liu, Z., Yang, J., Chang, Y., Weisberg, P.J. and He, H.S. (2012) Spatial Patterns and Drivers of Fire Occurrence and its Future Trend under Climate Change in a Boreal Forest of Northeast China. Global Change Biology, 18, 2041-2056. https://doi.org/10.1111/j.1365-2486.2012.02649.x

[11] De Rigo, D., Libertà, G., Houston Durrant, T., Artés Vivancos, T. and San-Miguel-Ayanz, J. (2017) Forest Fire Danger Extremes in Europe under Climate Change: Variability and Uncertainty. Publication Office of the European Union, Luxembourg, 71.

[12] Balch, J.K., Bradley, B.A., Abatzoglou, J.T., Nagy, R.C. Fusco, E.J. and Mahood, A.L. (2017) Human-Started Wildfires Expand the fire Niche Across the United States. Proceedings of the National Academy of Sciences of the United States of America, 114, 2946-2951. https://doi.org/10.1073/pnas.1617394114

[13] Krajick, K. (2005) Fire in the Hole. Smithsonian Magazine.

[14] Munroe, T. (2019) Embers under the Earth: The Surprising World of Coal Seam Fires.

https://www.globalforestwatch.org/blog/fires/embers-under-the-earth-the-surprisin g-world-of-coal-seam-fires

[15] Turco, M., Rosa-Cánovas, J.J., Bedia, J., Jerez, S., Montávez, J.P., Llasat, C.M., et al. (2018) Exacerbated Fires in Mediterranean Europe Due to Anthropogenic Warming Projected with non-Stationary Climate-Fire Models. Nature Communications, 9, Article No. 3821. https://doi.org/10.1038/s41467-018-06358-Z

[16] Emily, M., Douglas, K.B., Guy, M.R. and Delene, W. (2018) Generating Narratives on Bushfire Risk and Biodiversity Values to Inform Environmental Policy. Environmental Science and Policy, 89, 30-40. https://doi.org/10.1016/j.envsci.2018.07.001

[17] Olorunfemi, A., Timothy, E.R., Joe, D., George, B., Anna, M.A., Michael, T.K., Roger, D.O. and Luke, P.N. (2016) Review of the Health Effects of Wild Land Fire Smoke on Wild land Firefighters and the Public. Inhalation Toxicology, 28, 95-139. https://doi.org/10.3109/08958378.2016.1145771

[18] Joshua, W.D., Mel, T.D. and Christopher, B.D. (2020) Why Don't Bushfire Warnings Work as Intended? Responses to Official Warnings during Bushfires in New South Wales, Australia. International Journal of Disaster Risk Reduction, 45, Article 
ID: 101476. https://doi.org/10.1016/j.ijdrr.2020.101476

[19] Reid, C.E., Brauer, M., Johnston, F.H., Jerrett, M., Balmes, J.R. and Elliott, C.T. (2016) Critical Review of Health Impacts of Wildfire Smoke Exposure. Environmental Health Perspectives, 124, 1334-1343. https://doi.org/10.1289/ehp.1409277

[20] Moskwa, E., Bardsley, D.K., Weber, D. and Robinson, G.M. (2017) Living with Bushfire: Recognising Ecological Sophistication to Manage Risk while Retaining Biodiversity Values. International Journal of Disaster Risk Reduction, 27, 459-469. https://doi.org/10.1016/j.ijdrr.2017.11.010

[21] Harris, S. and Lucas, C. (2019) Understanding the Variability of Australian Fire Weather between 1973 and 2017. PLOS ONE, 14, e0222328. https://doi.org/10.1371/journal.pone.0222328

[22] Opha, P.D. (2013) Challenges of Wild Land Fire Management in Botswana: Towards a Community Inclusive Fire Management Approach. Weather and Climate Extremes, 1, 26-41. https://doi.org/10.1016/j.wace.2013.08.001

[23] Martine, D. and Michael, J.A. (2011) The Effects of Bushfire Smoke on Respiratory Health. Respirology, 16, 198-209. https://doi.org/10.1111/j.1440-1843.2010.01868.x

[24] Wayne, E.C. (2018) Wild Land Fire Smoke and Human Health. Science of the Total Environment, 624, 586-595. https://doi.org/10.1016/j.scitotenv.2017.12.086

[25] Dong, T.T.T., Hinwood, A.L., Callan, A.C., Zosky, G. and Stock, W.D. (2017) In Vitro Assessment of the Toxicity of Bushfire Emission: A Review. Science of the Total Environment, 603-604, 268-278. https://doi.org/10.1016/j.scitotenv.2017.06.062

[26] Eriksen, C. and Gill, N. (2010) Bushfire and Everyday Life: Examining the Awareness-Action "Gap" in Changing Rural Landscapes. Geoforum, 41, 814-825. https://doi.org/10.1016/j.geoforum.2010.05.004

[27] Fann, N., Alman, B., Broome, R.A., Morgan, G.G., Johnston, F.H., Pouliot, G. and Rappold, A.G. (2018) The Health Impacts and Economic Value of Wild Land Fire Episodes in the U.S.: 2008-2012. Science of the Total Environment, 610-611, 802-809. https://doi.org/10.1016/j.scitotenv.2017.08.024

[28] Gajendran, T. and Oloruntoba, R. (2017) Governance and Resilience: A Case of Re-Development after a Bushfire Disaster. Technological Forecasting and Social Change, 121, 50-64. https://doi.org/10.1016/j.techfore.2017.03.016

[29] Hobley, E.U., Le Gay Brereton, A.J. and Wilson, B. (2017) Forest Burning Affects Quality and Quantity of Soil Organic Matter. Science of the Total Environment, 575, 41-49. https://doi.org/10.1016/j.scitotenv.2016.09.231

[30] George, G.I., Daniel, G.N. and Paul, W.A. (2004) Effects of Wildfire on Soils and Watershed Processes. Journal of Forestry, 102, 16-20.

[31] Randerson, J.T., Chen, Y., Van Der Werf, G.R., Rogers, B.M. and Morton, D.C. (2012) Global Burned Area and Biomass Burning Emissions from Small Fires. Journal of Geophysical Research: Biogeosciences, 117, G04012. https://doi.org/10.1029/2012JG002128

[32] Raftoyannis, Y., Nocentini, S., Marchi, E., Sainz, R.C., Guemes, C.G., Pilas, I., Peric, S., Paulo, J.A., Moreira-Marcelino, A.C., Costa-Ferreira, M., Kakouris, E. and Lindner, M. (2014) Perceptions of Forest Experts on Climate Change and Fire Management in European Mediterranean Forests. IForest-Biogeosciences and Forestry, 7, 33-41. https://doi.org/10.3832/ifor0817-006

[33] Gonzalez-Caban, A. (2013) The Economic Dimension of Wild Land Fires. In: Goldammer, J.G., Ed., Vegetation Fires and Global Change: Challenges for Concerted International Action, 229-237. 
[34] NASA EarthData (2021) Global Fire Map. Climate Signals. https://www.climatesignals.org/data/global-fire-map

[35] Glasspool, I.J., Edwards, D. and Axe, L. (2004) Charcoal in the Silurian as Evidence for the Earliest Wildfire. Geology, 32, 381-383. https://doi.org/10.1130/G20363.1

[36] Edwards, D. and Axe, L. (2004) Anatomical Evidence in the Detection of the Earliest Wildfires. PALAIOS, 19, 113-128. https://doi.org/10.1669/0883-1351(2004)019\%3C0113:AEITDO\%3E2.0.CO;2

[37] Filkov, A.I., Ngo, T., Matthews, S., Telfer, S. and Penman, T.D. (2020) Impact of Australia's Catastrophic 2019/20 Bushfire Season on Communities and Environment. Retrospective Analysis and Current Trends. Journal of Safety Science and Resilience, 1, 44-56. https://doi.org/10.1016/j.jnlssr.2020.06.009

[38] IPCC (Intergovernmental Panel on Climate Change) (2014) Impacts, Adaptation and Vulnerability. Working Group II Contribution to the IPCC 5th Assessment Report. Intergovernmental Panel on Climate Change, Australasia, Chapter 25.

[39] Hughes, L. and Fenwick, J. (2015) The Burning Issue: Climate change and the Australian Bushfire Threat. Climate Council.

https://www.climatecouncil.org.au/burningissuereport2015

[40] Meyer, M., Galbally, I., Cook, G., Barrett, D., Tolhurst, K. and Graetz, D. (2001) A Spatially Explicit Inventory of Trace Gas Emissions from Wildfires and Controlled Burning over Australia. Cape Grim Baseline Air Pollution Station, Annual Scientific Meeting, Hobart, 6-7 February 2001.

[41] Tiernan, F. and O’Mallon, E. (10 January 2020) Australia's 2019-20 Bushfire Season. The Canberra Times.

[42] Lee, H. (2019) Bushfires Release over Half Australia's Annual Carbon Emissions.

[43] Singh, I. (2020) Top Maps and Charts that Explain the Terrifying 2019-20 Australian Bushfires. Geoawesomeness.

https://geoawesomeness.com/map-charts-graphics-explain-australian-bush-fires

[44] Pickrell, J. (17 December 2019) As Fires Rage across Australia, Fears Grow for Rare Species. Science. https://doi.org/10.1126/science.aba6144

[45] Hughes, L. and Alexander, D. (2017) Climate Change and the Victoria Bushfire Threat: Update 2017. Climate Council. https://www.climatecouncil.org.au/vicbushfires

[46] Deloitte Access Economics (2014) Scoping Study on a Cost Benefit Analysis of Bushfire Mitigation. Australian Forest Products Association.

http://ausfpa.com.au/wp-content/uploads/2016/01/AFPA-DAE-report-Amended-Fi nal-2014-05-27.pdf

[47] Bureau of Meteorology, Australia (2020) Annual Climate Statement 2019. http://www.bom.gov.au/climate/current/annual/aus/2019/\#tabs=Overview

[48] O’Neill, S.J. and Handmer, J. (2012) Responding to Bush Risk: The Need for Transformative Adaptation. Environmental Research Letters, 7, Article ID: 014018. https://doi.org/10.1088/1748-9326/7/1/014018

[49] McFarlane, A.C., Clayer, J.R. and Bookless, C.L. (1997) Psychiatric Morbidity Following a Natural Disaster: An Australian Bushfire. Society of Psychiatry and Psychiatric Epidemiology, 32, 261-268. https://doi.org/10.1007/BF00789038

[50] Country Fire Authority (13 May 2021) Radiant Heat-Country Fire Authority.

[51] Johnston, F., Hanigan, I., Henderson, S., Morgan, G. and Bowman, D. (2011) Extreme Air Pollution Events from Bushfires and Dust Storms and their Association with Mortality in Sydney, Australia 1994-2007. Environmental Research, 111, 
811-816. https://doi.org/10.1016/j.envres.2011.05.007

[52] Naeher, L.P., Brauer, M., Lipsett, M., Zelikoff, J.T., Simpson, C.D., Koenig, J.Q. and Smith, K.R. (2007) Wood Smoke Health Effects: A Review. Inhalation Toxicology, 19, 67-106. https://www.tandfonline.com/author/Smith\%2C+Kirk+R

[53] Brook, R.D., Rajagopalan, S., Arden Pope III, C., Brook, J.R., Bhatnagar, A., Diez-Roux, A.V., et al. (2010) Particulate Matter Air Pollution and Cardiovascular Disease: An Update to the Scientific Statement from the American Heart Association. Circulation, 121, 2331-2378. https://doi.org/10.1161/CIR.0b013e3181dbece1

[54] Morgan, G., Sheppeard, V., Khalaj, B., Ayyar, A., Lincoln, D., Jalaludin, B., Beard, J., Corbett, S. and Lumley, T. (2009) Effects of Bushfire Smoke on Daily Mortality and Hospital Admissions in Sydney, Australia. Epidemiology, 21, 47-55.

https://doi.org/10.1097/EDE.0b013e3181c15d5a

[55] Martin, K.L., Hanigan, I.C., Morgan, G.G., Henderson, S.B. and Johnston, F.H. (2013) Air Pollution from Bushfires and Their Association with Hospital Admissions in Sydney, Newcastle and Wollongong, Australia 1994-2007. Australian and New Zealand Journal of Public Health, 37, 238-243. https://doi.org/10.1111/1753-6405.12065

[56] Da Silva Viana Jacobson, L., de Souza Hacon, S., de Castro, H.A., Ignotti, E., Artaxo, P. and de Leon, A.C.M.P. (2012) Association between Fine Particulate Matter and the Peak Expiratory Flow of School Children in the Brazilian Subequatorial Amazon: A Panel Study. Environmental Research, 117, 27-35. https://doi.org/10.1016/j.envres.2012.05.006

[57] Jacobson, L.S., Hacon, S.S., de Castro, H.A., Ignotti, E., Artaxo, P., Saldiva, P.H., et al. (2014) Acute Effects of Particulate Matter and Black Carbon from Seasonal Fires on Peak Expiratory Flow of School Children in the Brazilian Amazon. PLoS ONE, 9 , e104177. https://doi.org/10.1371/journal.pone.0104177

[58] Haikerwal, A., Akram, M., Del Monaco, A., Smith, K., Sim, M.R. and Meyer, M. (2015) Impact of Fine Particulate Matter $\left(\mathrm{PM}_{2.5}\right)$ Exposure during Wildfires on Cardiovascular Health Outcomes. Journal of the American Heart Association, 4, e001653. https://doi.org/10.1161/JAHA.114.001653

[59] Van Eeden, L.M., Nimmo, D., Mahony, M., Herman, K., Ehmke, G., Driessen, J., O'Connor, J., Bino, G., Taylor, M. and Dickman, C.R. (2020) Impacts of the Unprecedented 2019-2020 Bushfires on Australian Animals. Report Prepared for WWF-Australia, Sydney.

[60] DEW-Department for Environment and Water, Government of South Australia. (2018) Glossy Black-Cockatoo.

[61] Hyman, I.T., Ahyong, S.T., Köhler, F., McEvey, S.F., Milledge, G.A., Reid, C.A.M. and Rowley, J.J.L. (2020) Impacts of the 2019-2020 Bushfires on New South Wales Biodiversity: a Rapid Assessment of Distribution Data for Selected Invertebrate Taxa. Technical Reports of the Australian Museum, 32, 1-17. https://doi.org/10.3853/j.1835-4211.32.2020.1768

[62] Sapkota, A., Symons, J.M., Kleissl, J., Wang, L., Parlange, M.B., Ondov, J., Breysse, P.N., Diette, G.B., Eggleston, P.A. and Buckley, T.J. (2005) Impact of the 2002 Canadian Forest Fires on Particulate Matter Air quality in Baltimore City. Environmental Science Technology, 39, 24-32. https://doi.org/10.1021/es035311z

[63] Zhou, N. (2019) Bushfire Death Toll Rises as Fires Weep across South Australia and NSW. The Guardian Australia.

[64] Readfearn, G. (2019) Australia's Bushfires Have Emitted 250m Tonnes of $\mathrm{CO}_{2}$, almost Half of Country's Annual Emissions. The Guardian Australia. 
[65] Otago Daily Times (2020) Australia Fires Sending "Pretty Hefty Smoke” New Zealand's Way. Radio New Zealand.

[66] The Guardian News \& Media (2020) Australian Bushfire Smoke Affecting South America.

[67] Neary, D.G., Ryan, K.C. and de Bano, L.F. (Eds.) (2005) Wildland Fire in Ecosystems: Effects of Fire on Soils and Water. General Technical Reports-USDA Forest Service. RMRS-GTR-42-vol.4, U.S. Department of Agriculture, Forest Service, Rocky Mountain Research Station, Ogden, 250 p.

[68] Brooks, K.N., Ffolliott, P.F., Gregersen, H.M. and De Bano, L.F. (2003) Hydrology and the Management of Watersheds. 3rd Edition, Iowa State University Digital Press, 704.

[69] Certini, G. (2005) Effects of Fire on Properties of Forest Soils: A Review. Oecologia, 143, 1-10. https://doi.org/10.1007/s00442-004-1788-8

[70] Chown, S.L. (2012) Antarctic Marine Biodiversity and Deep-Sea Hydrothermal Vents. PLoS Biology, 10, Article ID: 1001232. https://doi.org/10.1371/journal.pbio.1001232

[71] Brito, C. (2020) NASA Images Show Wildfires have Destroyed Nearly One Third of Australia's Kangaroo Island. CBSnews.com.

https://www.cbsnews.com/news/australia-fires-nasa-satellite-images-show-wildfires -destroy-kangaroo-island

[72] UN Environment Programme (2020) Ten Impacts of the Australian Bushfires. https://www.unep.org/news-and-stories/story/ten-impacts-australian-bushfires

[73] Santín, C. and Doerr, S.H. (2016) Fire Effects on Soils: the Human Dimension. Philosophical Transactions of the Royal Society B, 371, Article ID: 20150171. https://doi.org/10.1098/rstb.2015.0171

[74] Shakesby, R.A. and Doerr, S.H. (2006) Wildfire as a Hydrological and Geomorphological Agent. Earth-Science Reviews, 74, 269-307. https://doi.org/10.1016/j.earscirev.2005.10.006

[75] Martin, D.A. (2016) At the Nexus of Fire, Water and Society. Philosophical Transactions of the Royal Society B, 371, Article ID: 20150172. https://doi.org/10.1098/rstb.2015.0172

[76] Roach, J. (2020) Australia Wildfire Damages and Losses to Exceed \$100 Billion. AccuWeather Estimates.

[77] Martin, M. (2020) AM Best: Insurers Can Contend with Mounting Bushfire Losses. Insurancebusinessmag.com.

https://www.insurancebusinessmag.com/au/news/breaking-news/am-best-insurerscan-contend-with-mounting-bushfire-losses-211540.aspx

[78] Redfish Center (2017) Fire Ecology: How Does Fire Benefit Our Forest? Discoversawtooth.org.

https://discoversawtooth.org/fire-ecology-how-does-fire-benefit-our-forest

[79] Lyon, J., McInerney, P., Rees, G. and Joehnk, K. (2021) The Sweet Relief of Rain After Bushfires Threatens Disaster for Our Rivers. The Conversation.

https://theconversation.com/the-sweet-relief-of-rain-after-bushfires-threatens-disas ter-for-our-rivers-129449

[80] Aljazeera.com (2020) Nearly 3 Billion Animals Killed or Displaced by Australia Fires.

https://www.aljazeera.com/news/2020/7/28/nearly-3-billion-animals-killed-or-displ aced-by-australia-fires 
[81] Ward, M., Tulloch, A.I.T., Radford, J.Q., Williams, B.A., Reside, A.E., Macdonald, S.L., et al. (2020) Impact of 2019-2020 Mega-Fires on Australian Fauna Habitat. Nature Ecology \& Evolution, 4, 1321-1326. https://doi.org/10.1038/s41559-020-1251-1

[82] Brulliard, K. and Fears, D. (10 January 2020) A Billion Animals Have Been Caught in Australia's Fires. Some May Go Extinct. The Washington Post.

[83] Dvorsky, G. (9 January 2020) Wildfires Have Absolutely Ravaged Australia's Cherished Kangaroo Island. Earther.

[84] Khalil, S. (17 January 2020) Bushfires Bring “Apocalypse” to Kangaroo Island. BBC News.

[85] Marsh, J. (2020) I'm Searching Firegrounds for Surviving Kangaroo Island Micro-Trapdoor Spiders. 6 Months on, I'm yet to Find Any. The Conversation.

[86] ABARES (Australian Bureau of Agricultural and Resource Economics and Sciences) (2020) Agricultural Commodities: March Quarter 2020. Australian Bureau of Agricultural and Resource Economics and Sciences, Canberra.

[87] BBC News (2020) Australia Fires: A Visual Guide to the Bushfire Crisis. https://www.bbc.com/news/world-australia-50951043

[88] Arriagada, N.B., Palmer, A.J., Bowman, D.M.J.S., Morgan, G.G., Jalaludin, B.B. and Johnston, F.H. (2020) Unprecedented Smoke-Related Health Burden Associated with the 2019-20 Bushfires in Eastern Australia. Medical Journal of Australia, 213, 282-283. https://doi.org/10.5694/mja2.50545

[89] SBS News (2020) Bushfire Smoke Disrupts Canberra Hospital Services, Forces Attractions to Close.

https://www.sbs.com.au/news/bushfire-smoke-disrupts-canberra-hospital-services-f orces-attractions-to-close 